\title{
Responsibility to be Enthusiastic? Public Servants and the Public Face of 'Promiscuous Partisanship'
}

\begin{abstract}
"These were backroom people who relished being out of the limelight. There was a deal done that for concealed influence and some would say power, there was anonymity while they were doing it, apart from the appearance in the odd honours list, when they would shimmer discretely to the Palace for a gong or an upgrade gong and back again. But as a friend of mine used to say, rather unkindly of some individuals, they were scarcely household names in their own household."

Peter Hennessy - The Secret World of Whitehall, 2011, BBC Documentary.
\end{abstract}

The modern mandarin is no longer a creature of the shadows. The mid twentieth century civil service leaders described by Peter Hennessy above thrived in conditions in which quiet anonymity was simply a given. Their contemporary counterparts have found themselves sometimes reluctantly and sometimes not - drawn much further into the public gaze. As Rhodes has recently asserted: “...nowadays, senior civil servants speak in public almost as often as ministers" $(2011,9)$. Through mediums as diverse as social media, public speeches, media statements, parliamentary committee appearances, and public inquiries, senior public servants are emerging from anonymity to take their place alongside elected politicians as part of the 'public face' of government.

The reasons for this greater public exposure reflect a range of interconnected shifts in the pace and complexity of modern governance. A renewed focus on policy implementation and service delivery has occurred at a time when network governance has increased the complexity of negotiating successful policy outcomes. These difficulties now have to be negotiated more in the public eye than ever before, with more transparent decision-making being coupled with a more voracious media needing to feed a 24/7 news cycle. New Public Management has led to an outcomes-based performance culture, in which ministers, the parliament, and the press all expect a greater level of direct public accountability by public servants.

The shift to a higher public profile has, in turn, fed into an ongoing debate about how far public servants should be expected to go in publicly supporting the policies of the governments that they serve (see Mulgan 2007 and 2008; Wanna 2008). The late Peter Aucoin has argued that, taken collectively, changes to public administration in recent decades have seen the emergence of 'New Political Governance' (NPG). Amongst the characteristics of NPG in Aucoin's account is an assumption that public servants will act as 
'promiscuous partisans' in supporting the political agenda of the government of the day (Aucoin 2012, 179).

"Promiscuous partisanship", Aucoin argued, is made more dangerous by the degree to which public service leaders have become public figures who are asked to represent the government in an ever widening range of forums and roles.

But governments can also want their public service to be publicly supportive, even enthusiastic, about their agenda and to promote it in their consultations with stakeholders as well as in their delivery of services directly to the public. To the degree that governments have this expectation of enthusiastic support, it goes beyond the traditional requirement of loyalty to the government of the day. It substitutes partisan loyalty for impartial loyalty. The risk of politicization is enhanced by the fact that public servants, at various levels, are now much more exposed publicly in their dealings with stakeholders, organized interests, individual citizens, the media, and parliamentarians. The anonymity of public servants, as invisible to parliament or the public, disappeared some time ago. In the environment of NPG, moreover, ministers, sometimes explicitly, usually implicitly, expect those public servants who are seen and heard in countless public forums to support government policy, that is, to go beyond mere description and explanation. (Aucoin $2012,189)$

Aucoin goes on to provide some useful examples of promiscuous partisanship in Australia, Canada and the United Kingdom. What is missing is a clear line between what might be considered appropriate 'responsiveness' to ministers and what should be considered inappropriate 'partisan' behavior. Is promiscuous partisanship an inherently 'bad' activity, or does it only become a problem if it renders a public servant unable to offer the same level of support to an incoming government of a different political stripe?

Aucoin's examples include a civil servant editing a book supportive of government policy in the United Kingdom, and the appearance of a public servant in a government advertisement in Australia. I argue that what makes these two cases problematic is not the activity itself, but its public nature. The more that public servants are placed in the public eye, the more their activities can give rise to perceptions of partisanship (Lindquist and Rasmussen, 2012, 191). Public servants have loyally drafted and supported government policy for decades - it's part of their core role. It's only when individual public servants adopt a public face of their own - separate from that of their minister - that concerns arise. In other words, what has changed is not partisan behaviour (which is always a matter of perception) but the decline in anonymity that has elevated senior public servants to the public stage in their own right.

Aucoin's third example relates to the uncritical carrying out of ministerial instructions by Canadian public servants in the Sponsorship Scandal. But did the failings in this case belong more to the bureaucracy or to ministers themselves? Public servants are 
meant to implement government policy. It's their job. In the case of the Sponsorship Scandal, it could certainly be argued that a degree of frank and fearless behaviour and good judgement may have been missing, but that is a different question to allegations of 'partisanship'. It is hard to disagree with Lindquist and Rasmussen's recent conclusion that "what was notable was how few professional public servants were implicated" $(2012,195)$. As Prime Minister Harper told public servants when introducing the new 2006 Federal Accountability Act in response to the Sponsorship Scandal: "'[y]ou didn't cross the line. Your political masters did" (Harper 2006, para 18).

The 'responsiveness' debate is centred on this point - on how far public servants have a duty to 'stand up' to the government of the day when they perceive that ministers are 'crossing the line'. Even the most strident critics of overly responsive public servants concede that decision-making rightly remains the preserve of ministers. Once public servants have given their frank and fearless advice, they have no right to sulk in a corner if their advice is not taken. Instead they must get on and implement government policy. What is to be avoided is perhaps not so much 'partisan' behaviour as a lack of judgement and prudence in assessing the appropriateness of government directives to public servants. In the case of the Sponsorship Scandal, the failure to provide frank and fearless advice has no logical link to being partisan as opposed to being overly responsive.

Once public servants shed their anonymity and are seen to publicly support or defend government policy, the distinction between appropriate responsiveness and inappropriate partisanship takes on a sharper edge. It is no secret that governments spend a significant amount of their time trying to shape public perceptions - cynics would say "spin" - about their policy agenda. It is an aspect of contemporary governance that self evidently has an impact on the work of public servants when they are asked to publicly support and implement that agenda. Aucoin's account raises important questions about how contemporary Westminster public services are reacting to changing demands and expectations on what their role should be. Are institutional structures and guidelines encouraging public servants in Westminster system countries to become public advocates for government policy? If so, is this an abrogation of fundamental tenets of the Westminster system, or merely a form of institutional stretching that re-shapes but does not break traditional bonds of impartiality?

This article seeks answers to these questions through a comparative analysis of public service codes and guidelines across four established Westminster democracies: Australia, Canada, New Zealand and the United Kingdom. It argues that across all four jurisdictions there is evidence of governments seeking a greater level of proactivity from public servants in their public explanations of government policy - but that this stops short in most cases of formally institutionalizing a new "promiscuous partisanship". In the United Kingdom case, the evidence in support of the promiscuous partisanship thesis is at its strongest and it is argued here that the formal guidelines leave little room for civil servants 
to resist pressure to actively justify government policy. In all cases, a tension remains between institutionalised understandings of how Westminster systems should work, and the individual interpretations of public servants on where the line between partisanship and impartiality lies.

My focus here is primarily on the upper echelons of the public service in each jurisdiction. The mandarins were the main focus of Aucoin's NPG concerns because of their ability to either promote or resist a more politicized culture within their organisations. It is at this level that concerns about too much responsiveness have led to debates on how far diminished job security amongst public service leaders has led to less frank and fearless advice and whether this has undermined the 'neutral competence' public service model (Boston and Halligan 2012; Podger 2007a and 2007b; Shergold 2007). But lower-ranking public servants are not immune. The same issues are faced by any public servant who has a public aspect to their role. This includes press officers for example, whose difficulties are discussed below in the United Kingdom case.

\section{Emerging from Anonymity}

Rhodes, Wanna and Weller (2009) locate the institutional behavior of public bureaucracies within a collection of traditions and beliefs that form mutual understandings of what Westminster is. Utilising an interpretivist approach they examine what Westminster means to the public service leaders who work within it. They distinguish between the "political traditions" of responsible government - encompassing the established decision-making and accountability conventions - and "administrative traditions" (2009, 157-158). The latter encompass the "...evolving notions of professionalism, degrees of independence, expertise and technical proficiency, management, and preferred patterns of recruitment and workforce composition" $(2009,158)$. The traditional commitment to the anonymity of the public service - and its relationship to conventions of non-partisanship - exists within this dual realm of political and administrative tradition. These traditions are then either buttressed or challenged by the impacts of formal laws such as freedom of information requirements and 'soft' laws like codes of conduct and codes of ethics. It is these latter codes that I will argue provide an important guide for public servants as they assess how institutionalised traditions should apply to their own behavior.

Anonymity, like so much in the Westminster tradition, is an idea that emerged through practice and convention over time. The Northcote-Trevelyan Report of $1854-$ rightly celebrated as the foundation stone of modern Westminster-style civil services - was silent on both anonymity and impartiality (Rhodes et al 2008, 468). And yet, both concepts have now found an established place in understandings of Westminster convention. In their groundbreaking study of 1970's bureaucracy, Aberbach, Putnam and Rockman described the politically insulated nature of the Civil Service in Britain and the Netherlands: 
These are precisely the systems in which administrators are institutionally most insulated from the world of overt politics, where civil servants generally operate under the veil of anonymity, and where ministerial responsibility, collective cabinet government, and a party-centered parliament are most fully developed. $(1981,233)$

At one level, the contemporary challenges to this traditional anonymity have little to do with the personal wishes of senior bureaucrats and everything to do with the increased willingness of politicians and the public to hold them more directly accountable for management mistakes. For example, rather than ministers taking responsibility for whatever mistakes are made by their department - as Westminster convention in theory demands - they are now sometimes using civil servants as their shield against public disapproval. To quote from a study by Van Dorpe and Horton (2011, 246-247):

The decreased anonymity is not only due to the increased exposure by ministers, but also a consequence of the ever more intrusive media. A complaint was filed by the First Division Association - the union representing senior civil servants - in 2006 on the use of senior civil servants as scapegoats for faults committed by politicians.

The increasing requirements of open accountability to parliament or its committees by senior public servants have also contributed to the greater public profile of mandarins. Scholars have noted this shift in the United Kingdom (Van Dorpe and Horton 2011), Canada (Bourgalt 2011), and Australia (Dixon et al 1996; Weller 2001, 154). Interestingly, Kernaghan was already discerning a shift away from anonymity in the late 1970s because of the need for officials to 'explain government policies in public forums', and the increasing inquisitiveness of journalists $(1979,391)$.

But the impacts of such changes are not necessarily uniform across the Westminster world. In some jurisdictions, the culture of transparency and accountability has arguably actually helped to protect public servants from being seen as partisan in the advice they give. For example, the freedom of information environment in New Zealand allows journalists to compare government decisions with the advice that was given by public servants. In other words, it becomes a matter of open public record that a public servant has disagreed with a minister, lessening the level of blame that can attach to public servants for whatever outcomes may result (Boston and Halligan 2012, 218-219).

\section{Agency-Centred Historical Institutionalism and the Promiscuous Partisan}

Aucoin makes clear that his charge of 'promiscuous partisanship' relies as much on informal conventions and behaviours as it does on formal guidelines of behaviour. Aucoin asserts that: 
The culture of promiscuous partisanship is nowhere articulated as the norm for the public service. Everywhere, impartiality remains the official doctrine. Indeed, if anything, it is asserted more often now as codes of conduct and values are proclaimed. Yet, breaches are commonplace. (Aucoin 2012, 189)

Aucoin's assertion sets up a classic analytical dichotomy between the influence of structure versus the influence of agency on the behaviour of actors - in this case the behaviour of public servants and the ministers who direct them. Aucoin essentially asserts that despite the institutionalised traditions of the Westminster system, and the structural support of guidelines that stress the importance of impartiality, public service actors are interpreting and constructing their behaviours based on their perception of what ministers want.

The challenge for that approach in this context is that individual behaviours are being used to suggest systemic failure, without a commensurate body of evidence to show that promiscuous partisanship has indeed permeated further than the individual actions of a handful of senior public service leaders. Both Boston (2012) and Nethercote (2012) in their critiques of Aucoin's thesis suggest that the evidence of a systemic change is slim. Aucoin's individual examples of behaviour by senior public servants are important but not conclusive in themselves. It is equally possible to cite counter examples, such as the decision by the Australian Secretaries of Finance and Treasury to issue a joint media release during the 2013 election campaign contradicting the public statements of ministers about policy advice they had been given by the public service (Parkinson and Tune 2013).

In other words, I argue that the structural and institutional importance of guidelines on values, ethics and conduct for public servants cannot be so lightly dismissed. Their capacity to shape boundaries for behaviour and to protect public servants from political pressure is significant. Bell's (2011) work developing a theory of agency-centred historical institutionalism is instructive here. Bell argues that the nature of institutions can and does effect the options that individual actors perceive as being available to them - even when exercising an important degree of individual agency. The nature of those structural boundaries can range from formal instruments or guidelines that set out expected behaviours through to received wisdoms on accepted norms. As the work of Rhodes (2011) illustrates, institutional shape can in part be derived from received traditions passed down as 'stories' about how a department functions. Such stories can create a kind of interpretive historical institutionalism as contemporary actors draw on the stories of those who have gone before.

The combined conventions, traditions and stories of how bureaucrats should behave in a Westminster environment form part of the institutional structure that determines whether individual actors perceive themselves as promiscuous partisans or not. Equally, the structure provided by guidelines on appropriate behaviour sets important parameters for the exercise of agency. To the extent that a public servant can say 'no' to a ministerial request that they believe to be inappropriate, it is the ability to point to structural guidelines 
that gives their case some formal authority. It is much easier to say 'no' to a minister if you can point to a specific guideline that the proposed instruction is breaching, rather than simply saying it doesn't sit well with one's own interpretation of how things should be done. Utilising the theoretical framework provided by agency-centred historical institutionalism, the following sections provide a comparative account of the formal rule structures that shape the ability of public servants to exercise a degree of personal agency as public actors.

\section{Australia}

In Australia, the responsibilities of public servants are encapsulated in the Australian Public Service (APS) Code of Conduct and the APS Values. These are supported by interpretations made in documents such as the Australian Public Service Commissioner's Directions, and through guidance published on the Australian Public Service Commission (APSC) website. The Commissioner's Directions for 2013 provide clarity in Chapter 1.6 on what it means for public servants to act impartially, as required under the APS Values.

(a) serving the Government of the day, providing the same standard of high quality policy advice and implementation, and the same high quality professional support, irrespective of which political party is in power and of personal political beliefs; (APS Commissioner 2013, Ch. 1.6)

This impartial service must however be provided in a way that shows public servants are "(d) understanding the needs of the Government..." and "(f) providing advice that takes account of the context in which policy needs to be implemented, the broader policy directions set by Government and, where appropriate, implications for the longer term" (APS Commissioner 2013, Ch. 1.6).

Advice and behaviour certainly needs to be impartial and non-partisan, but must also reflect the priorities of the government of the day. So how far should public servants interpret this as a responsibility to enthusiastically and publicly support government policy? The APSC provides guidance directly on the topic in its advice on "Involvement of public servants in public information and awareness initiatives" (APSC n.d.) The guidelines make clear that public servants cannot simply hold themselves aloof from public engagement on the grounds that it is an inherently political activity.

Australian public servants have a legitimate role in helping to explain to the Australian community how Government policy decisions and initiatives will be implemented, how they will operate and how they will affect rights, entitlements and responsibilities. (APSC n.d.)

But in undertaking these duties, public servants are walking a precarious and inherently contested tightrope in explaining government policies that are the subject of 
fierce and sustained political criticism from the opposition and public interest groups. The rules do not attempt to hide the complexity of this task:

The APS Values mean that public servants should not become involved in any official capacity with promoting or commenting on a Government policy. Similarly, public servants should not in any official capacity criticise or comment on the policies of the Opposition or other political organisations. Agency resources are not to be used to support political campaigns.

But these Values also mean that public servants have a duty to effectively, professionally and proactively explain and implement Government policies and programmes and to ensure that the community fully understands how these policies and programmes will operate and what their rights, entitlements and obligations might be. (APSC n.d.)

The guidelines recognise that: "The issue of what might or what might not appear to be political may vary in different circumstances and agencies and individual public servants will need to be aware of and manage certain risks" (APSC n.d.). The rules then go on to differentiate between the "explanation of Government policies and programmes" - which is seen as part of the "core responsibility" of the public service - and "public information" promotion, which needs "to be considered very carefully" (APSC n.d.).

In drawing the distinction between explanation and promotion, the rules embrace a very wide ambit for the former in terms of the ability of public servants to adopt a public face. Explanation involves far more than just the normal public interaction at service counters by street level bureaucrats. It can include "speaking at public forums and engaging in public discussions" and "developing and appearing in written information material targeting the public such as Government leaflets, booklets and newsletters" (APSC n.d.). Appearance in the media can be actively embraced where appropriate by "contributing articles to non-government newspapers, magazines and journals" and "responding to media queries and participating in media interviews and discussions, including on radio and television" (APSC n.d.). In other words, public servants are empowered to explain government policy in pretty much any forum and media that they deem appropriate. But, as the rules again make clear, it would be naïve to think that the distinction between explanation and advocacy is clear cut and uncontroversial.

Effective explanation of Government policies and programmes may involve both straight information and as well as comment designed to explain and highlight elements of this information. A key issue is the extent to which comment might be perceived as advocacy, and this will require judgement in individual cases. Again, the rule of thumb is that it is the Government's responsibility to explain why a policy or programme decision has been taken and the public servant's responsibility to explain what the decision means and how it will operate. (APSC n.d.) 
But this should not stop public servants from correcting "misconceptions" about how government policies are to work - another activity that is extraordinarily difficult to distinguish from political arguments that might be taking place about that policy.

An important element in implementing and explaining Government policies and programmes may be the need to counter community and stakeholder misconceptions. Care may need to be taken to ensure that attempts to correct these errors are not perceived as criticisms of the Opposition or of other stakeholders. In these circumstances, a statement of the facts in neutral language is less likely to be perceived as 'political' than a direct refutation of Opposition or other political stakeholder claims. (APSC n.d.)

\section{New Zealand}

The New Zealand State Services Commission released a Political Neutrality Guidance in 2010 to help explain - in plain English terms - how public servants could go about maintaining political impartiality. "This means, essentially, that State servants must keep their jobs out of their politics and their politics out of their jobs" (State Services Commission 2010b, 1). This is especially so for those staff who work most closely with the ministers of the day.

The rights of political expression and association must be balanced against the well established convention that senior State servants who have regular direct contact with Ministers ought not to publicly express any view either for or against the policies of the Government of the day. This may mean for staff actively engaged in providing advice to Ministers on a particular issue, that it is not appropriate to participate in public protest and political activity centred on that issue. (State Services Commission 2010b, 2)

This specific guidance on political neutrality is supported by the wider Standards of Integrity and Conduct for State servants. The State Services Commission provides guidance to underpin these standards in its Understanding the Code of Conduct - Guidance for State Servants. The relevant guidance for public speaking in an official capacity is provided under the standard: "We must respect the authority of the government of the day" (State Services Commission 2010a, 15). The guidance is noticeably restrictive in its interpretation of the role of the State Service in providing comment on government policy on behalf of an organisation.

Ministers set and comment on government policy. The role of most of us in the State Services is to explain and give effect to that policy. A few State servants hold statutory roles that from time to time may require them to comment publicly about government policy. Some of us work in organisations with independent decisionmaking or advocacy responsibilities and may be authorised to comment publicly on policy issues. It is only if we have one of these exceptional roles that we may 
comment about government policy on behalf of our organisation. (State Services Commission 2010a, 15)

This suggests that the ability to comment is limited to the kind of statutory or crown authority that operates at arms length from government, as opposed to the line departments that are directly responsible to their minister. The guidance attempts to engage with the crucial question of the perception of behaviour as well as the actual behaviour. "We must bear in mind the sensitivity that both current and future Ministers may have about our involvement in high-profile activities that could be viewed as party political" (State Services Commission 2010a, 15). The guidance warns against the general unacceptability of revealing information not yet known to the public, purporting to "express or imply an organisational view", or "criticise in such strong or persistent terms that our ability to give full effect to the executive government responsibilities of our organisation in an impartial way is called into question" (State Services Commission 2010a, 16).

\section{United Kingdom}

At the home of Westminster, so long governed by the unwritten conventions of how civil servants should behave, there has been a move in the last two decades towards clear written rules on what is expected of civil servants. The Civil Service Code, similar to the codes in Australia and New Zealand, provides the broad parameters for civil service behaviour. The Cabinet Office has put out documents including the full Directory of Civil Service Guidance and the more specific Propriety Guidance, which was released through the Government Communications Network in 2013 to deal specifically with civil servants and government communications.

The Civil Service values and accompanying code, legislated through the 2010 Constitutional Reform and Governance Act, provide directions to all civil servants on the meaning of 'political impartiality'. The Code stipulates that Civil Servants must:

- serve the Government, whatever its political persuasion, to the best of your ability in a way which maintains political impartiality and is in line with the requirements of this Code, no matter what your own political beliefs are;

- act in a way which deserves and retains the confidence of Ministers, while at the same time ensuring that you will be able to establish the same relationship with those whom you may be required to serve in some future Government. (Civil Service Code 2010, section 14)

What this necessarily general formulation does not provide is guidance on where the line is between unacceptable partiality and acceptable 'responsiveness'. All that is prohibited is enacting one's own political beliefs. 
The 2013 Propriety Guidance is far more specific in the level of support or even enthusiasm that civil servants are expected to demonstrate for government policy. The guidance is targeted especially at those civil servants who have regular interactions with the media as part of their normal duties - i.e. press officers - but its scope is not limited to those officers. The rules would seem to apply to any civil servant engaged in a communication act on behalf of the government. To begin with, the guidance openly recognises the inability to entirely divorce impartial communications from questions of the political benefit that governments derive from it.

Publicly funded government communications cannot be used primarily or solely to meet party political objectives. However, it is recognised that the governing party may derive incidental benefit from activities carried out by the Government. (Cabinet Office n.d., 5)

The guidance then sets out what the Government has the "right" to expect of its civil service press officers in particular and refers specifically to the "ministerial line".

It is the duty of press officers to present the policies of their department to the public through the media, and to try to ensure that they are understood. The press officer must always reflect the ministerial line clearly, even where policies are opposed by opposition parties. As part of the Government's duty to govern, it needs to explain its policies and decisions to the electorate. The Government has the right to expect the department to further its policies and objectives, regardless of how politically controversial they might be. (Cabinet Office n.d., 6)

The incredibly fine judgement calls that this asks of civil servants are then highlighted by stating that press officers "have a duty...to remain objective and impartial, especially when dealing with politically controversial issues" (Cabinet Office n.d., 6). The inherent tension between following a "ministerial line" and remaining "objective and impartial" is left to civil servants to manage. As Mulgan's research demonstrates, expecting civil servants to propound a public view in contentious policy debates threatens public perceptions of their impartiality (Mulgan 2008, 349).

This tension reaches a further pitch of difficulty in the 2013 Propriety Guidance in the list of "press office dos and don'ts" that follows. Press officers are told that they should:

- Present, describe and justify the thinking behind the policies of the minister.

- Be ready to promote the policies of the department and the Government as a whole.

- Make as positive a case as the facts warrant. (Cabinet Office n.d., 6)

The inclusion of the word "promotion" rather than the more traditional "explanation" is a significant raising of the bar in terms of the level of enthusiastic support being asked of civil service press officers. Even more significant perhaps is the expectation 
that civil servants will seek to "justify the thinking behind the policies of the minister." This goes far beyond explanation and even promotion because it asks civil servants to defend the thinking of ministers - an activity that is self-evidently not an impartial one. The third point underlines this requirement by effectively institutionalising a responsibility to spin by making "as positive a case as the facts warrant." It's not just about objectively presenting facts, but doing so in the most "positive" light that the facts will allow. It would be hard to think of a clearer definition of spin in modern politics.

The current UK guidelines must necessarily be read against the backdrop of changes instituted during the first term of the Blair Government. Under the direction of Blair's communications head - Alistair Campbell - departmental media officers were expected to be much more forthright in their support of government policy. The simple provision of information to media outlets was not sufficient. A greater degree of proactive advocacy was expected (see Wilson and Barker 2003, 369; Hennessy 2000, 488-89).

A recent report from the Institute for Public Policy Research (IPPR) comparing the accountability and responsiveness of senior civil servants in different jurisdictions makes clear that each country has its own unique set of arrangements (Institute for Public Policy Research 2012). In particular, the United Kingdom has been more reluctant than other countries to provide ministers with large numbers of politically appointed advisers who can more clearly prosecute the minister's political agenda. The IPPR report argues that one of the reasons Australian, Canadian and New Zealand governments have opted for large numbers of advisers in private offices is to insulate the rest of the public service from pressure to become involved in political matters.

In that light, the 2013 Propriety Guidance could be viewed as an attempt to meet the political needs of government by co-opting civil servants to undertake tasks that might be done by political appointees in other jurisdictions. The weakness of that proposition is the fact that the area where British governments have been the most prepared to appoint special advisers is in the media and communications area. In other words, if political advisers are already being hired to spin for the government, the institutional justification for co-opting civil servants to undertake the task is decreased.

\section{Canada}

In Canada, the 2011 Values and Ethics Code for the Public Sector provides the overarching guidance on public servant behaviour. Like all three of the other jurisdictions already discussed, the Code maintains the centrality of impartiality to the working of a successful public service. Under the value of 'Respect for Democracy', the Code states: 
Public servants recognize that elected officials are accountable to Parliament, and ultimately to the Canadian people, and that a non-partisan public sector is essential to our democratic system. (Government of Canada 2011, 3)

The Public Service Commission of Canada (PSCC) provides more specific guidelines on "Safeguarding non-partisanship in the Public Service" (PSCC 2013), but these relate specifically to safeguarding merit-based selection in hiring and to regulating the political activities of public servants who might wish to run as a candidate in an election or engage in other political behaviour. It provides little clarity for how public servants should act publicly when acting in their official capacity. In July 2008, the PSCC released a publication entitled Public Service Impartiality: Taking Stock, which provides a very clear discussion of the various dimensions of impartiality as it relates to the work of public servants.

The document re-iterates the traditional distinction between explanation of policy and the defence or advocacy of it.

Although public servants are to be sensitive to partisan considerations, they are not actively to support or debate policy decisions. While they may be required to explain policy rationale, public servants are not to argue in favour of or against a particular policy. (Furi 2008, para 5.13, p.18)

The inherent tension between loyalty to the government and the duty of impartiality is clearly acknowledged. "The paradox is that public servants must be non-partisan, while remaining loyal to a legal entity whose powers are exercised by a political body" (Furi 2008, para 5.18 , p. 19).

Public Service Impartiality: Taking Stock goes on to highlight that it is the public nature of what public servants do or say that ultimately determines the degree to which perceptions of politicisation will emerge.

Regardless of how the visibility of public servants has increased, the more visible public servants are, the more vulnerable they become to partisan political attacks. If public servants are attacked publicly by one party and praised by another, this could undermine public service impartiality. This issue is further complicated when one considers the statutory authorities and responsibilities given to deputy heads. (Furi 2008, para 6.4, p. 21).

The Treasury Board of Canada Secretariat displays the Communications Policy of the Government of Canada on its website. This largely high-level document sets out the communications requirements expected of organisations operating as part of the Canadian Public Service. Bureaucratic leaders are directed to uphold the "...integrity and impartiality of the Public Service of Canada" (Treasury Board of Canada Secretariat 2012, point 9). 
Canadians value an independent, professional Public Service that treats individuals with respect, fairness and integrity. The value and reputation of public institutions must be honoured. Public service managers and employees are expected to provide information services in a non-partisan fashion consistent with the principles of parliamentary democracy and ministerial responsibility. (Treasury Board of Canada Secretariat 2012, point 9)

The rules mandate that relations with the media must be cultivated, but only to raise "awareness" and "understanding" of government policy, rather than extending to justifying those policies as the UK guidelines suggest. "Institutions must cultivate proactive relations with the media to promote public awareness and understanding of government policies, programs, services and initiatives" (Treasury Board of Canada Secretariat 2012, policy requirement 19). But the document equally makes clear that it is ministers and not public servants who carry the responsibility of explaining government policies.

Ministers present and explain government policies, priorities and decisions to the public. Institutions, leaving political matters to the exclusive domain of ministers and their offices, focus their communication activities on issues and matters pertaining to the policies, programs, services and initiatives they administer. (Treasury Board of Canada Secretariat 2012, policy requirement 20)

The policy suggests that the role of public servants is to "inform" citizens about the contents of government policy - stopping well short of either explanation or justification.

[1]nforming the public about policies, programs, services and initiatives in an accountable, non-partisan fashion consistent with the principles of Canadian parliamentary democracy and ministerial responsibility. (Treasury Board of Canada Secretariat 2012, Appendix B)

There has been recent debate in Canada about the effect of the 'Message Event Proposal' (MEP) system instituted by the Harper Government (see Thomas, 2013). The MEP process centralised government-wide communications control in the Prime Minister's Office (PMO), including control over the events and speeches of senior public servants. At one level, the practice certainly supports Aucoin's overarching NPG thesis by suggesting an intense desire on the part of ministers - and especially the prime minister - to exert political control over every aspect of public service activity. Whether or not this leads to perceptions of public service partisanship relies significantly on how individual public servants respond to the attempts at control and how willing they remain to exercise their own judgement in choosing what to say at public events. 


\section{Significance and Discussion}

Each jurisdiction under examination here has produced guidelines covering various aspects of the values and behaviours expected of public servants. This includes specific guidelines on the level of public support for governments that is expected and appropriate. In all four cases, these guidelines certainly encourage the clear explanation - sometimes in the face of criticism - of the policies of the government of the day. At the same time, in all four cases, the rules specifically state the ongoing importance of impartiality and non-partisanship as foundation stones of how a public service operates.

In the New Zealand case, the rules stop short of asking public servants to inject some form of enthusiasm for government policy that goes beyond the explanation of how policy works. This contrasts with both Australia and Canada where a degree of 'proactivity' is encouraged in the way public servants engage with the media. Under the Canadian Treasury Board Secretariat rules, "Institutions must cultivate proactive relations with the media to promote public awareness and understanding of government policies, programs, services and initiatives" (Treasury Board of Canada Secretariat 2012, policy requirement 19). Similarly, the Australian rules stipulate a duty for public servants to "effectively, professionally and proactively explain and implement Government policies" (APSC n.d.). The imperative of proactivity is significant because it suggests a level of enthusiasm is required in order to actively seek out opportunities to explain policies rather than waiting to be asked.

The New Zealand and Canadian rules are quite explicit that it is the job of ministers not public servants - to promote and comment upon the political reasons for policy decisions. But in the Canadian case, this wider point juxtaposes somewhat awkwardly against the requirement that public service institutions "promote public awareness and understanding of government policies, programs, services and initiatives" (Treasury Board of Canada Secretariat 2012, policy requirement 19). The lines between "explanation" of policy, "promotion" of policy, and the open defence of policy are impossible to set with a clarity that can defy any blurring. This has two potentially significant consequences. Firstly, it allows significant room for the exercise of individual discretion by public servants in deciding how far they can reasonably go in their public explanations of government policy. So - in terms of an institutions versus agency analysis - individual agency remains important, albeit within the bounds established by the institutional structures through which the agents are operating. Secondly, it creates the inevitability that public appearances by public servants will lead to perceptions that they have become politicised, even when they are in reality taking every precaution not to be.

If public servants are encouraged to appear in the media and elsewhere to explain government policy settings, they can become tightly and closely associated with the policy itself in the public mind. Paradoxically, whilst acting with integrity and impartiality in carefully keeping within Westminster conventions, public servants can nevertheless find 
themselves in the middle of political firestorms. The position of former Australian Treasury Secretary Ken Henry in the Mining Tax debate in Australia in 2010 is one recent example. At the request of the Rudd government, Henry undertook a sweeping review of the Australian taxation system in 2008-10. Amongst his recommendations was that the government adopt a new way of taxing profits from natural resources to maximise the returns from the mining boom. The Rudd government in 2010 committed to a Resource Super Profits Tax without fully adopting Henry's proposal. What followed was a protracted partisan political battle as the Opposition opposed the new tax, and Henry faced criticism suggesting that he had politicised his position by being too supportive of the government's position (AAP 2010).

In a different way, but with similar consequences, the current UK Cabinet Secretary Sir Jeremy Heywood's role in the "Plebgate" affair generated intense media scrutiny in 2012-13. The "Plebgate" affair revolved around the remarks of the then government Chief Whip, Andrew Mitchell, when he was alleged to have called police officers "Plebs" for not letting him ride his bike out of the gates at Downing Street. At the request of the Prime Minister, Heywood conducted an initial inquiry into aspects of the matter. He was subsequently heavily criticised by the House of Commons' Public Administration Committee over his handling of the inquiry, and for having agreed to carry out such an inquiry in the first place when he was not the right person to do so. Those criticisms were widely publicised in the media (see for example: Sparrow 2013; Ross 2013). In both the Henry and Heywood cases, it could be argued that public servants were legitimately responding to the instructions of ministers, only to find themselves repeatedly criticised by Opposition MPs and the media because of the public nature of their role.

Perhaps in order to avoid such situations, the New Zealand rules seek to minimise public comment all together. They stress that "[i]t is only if we have one of these exceptional roles that we may comment about government policy on behalf of our organisation" (State Services Commission 2010a, 15). The New Zealand rules specifically warn against individuals purporting to "express or imply an organisational view" (State Services Commission 2010a, 16). At the highest levels of the public service, this can create difficulties for senior leaders engaged in placing broad policy options before the government and the public. It is certainly not unusual in public speeches by Treasury Secretary's to hear them refer to "Treasury's view" on a particular policy conundrum - carefully expressed so as not to contradict any existing government policy.

The United Kingdom approach is notably different. Especially in its language regarding the duties of press officers, it entrenches an expectation of full-throated support for the government of the day, regardless of how contentious a policy might be. The guidelines specifically ask civil service press officers to follow the "ministerial line", and present information as positively as possible whilst "justifying" the thinking of their ministers to the wider public through the media. Aucoin's argument was essentially that despite the claims within codes of conduct and guidelines that impartiality was a central 
value - public servants were being pressured to act in politically partisan ways. In one sense, the current UK approach takes Aucoin's argument one step further by actually formalising a degree of promiscuous partisanship within the guidelines themselves.

As all the relevant documents indicate, discretion and judgement remain at the core of how public servants behave when confronted with blurred lines between impartiality and serving the government that they are responsible to. Each of the jurisdictions examined acknowledges that the individual judgement of public servants on what is the right thing to do remains central. The extent to which 'promiscuous partisanship' is displayed publicly by public servants can therefore best be understood within a theoretical framework of agencycentred historical institutionalism. Clear rules have emerged over decades of Westminster practice and been codified in modern documents on values and ethics, but in each case these rules remain to be interpreted by the individual actors who must abide by them. Those actors can and do of course also draw on collegial discussion with peers, and their own past experience, in arriving at their professional judgement on any given matter. Institutional structures such as guidelines and codes of conduct do not exclude other factors from influencing an agent's decision-making - but they provide the formal parameters in which it occurs. The importance of the guidelines remains because they can either protect the traditional values of impartiality and non-partisanship, or they can begin to normalise and even institutionalise a fundamental change in Westminster traditions in favour of more partisan behaviour.

It is argued here that - taken collectively - the guidelines in Australia, New Zealand and Canada do suggest that governments expect the public support of the public service in promoting government policy, but that this is not fundamentally at odds with traditional Westminster expectations of the public service. Public servants have always been expected to serve the government of the day by implementing its policies, regardless of their own political views and the views of the previous government. Does the suggestion that they should do so with greater levels of enthusiasm automatically mean they cross a line into the kind of partisanship that will prevent them being able to serve the next government? Arguably it stretches traditional Westminster bounds, but does so in an evolutionary way that doesn't render current practice as unrecognisable based on earlier traditions. Further studies will provide important empirical data on the extent to which other emerging pressures - such as the increasing use by government of PR professionals, and the rising importance of social media - are pushing public servants into new spheres of activity not covered by existing Westminster conventions.

In contrast, the United Kingdom case seems to provide a qualitative shift towards exactly the kind of public promiscuous partisanship that Aucoin was warning against. The United Kingdom Proprietary Guidance clearly enshrines a level of support for "ministerial lines" of communication by civil service press officers that is difficult to distinguish from open advocacy. The language specifically asks civil servants to express "...the ministerial line 
clearly, even where policies are opposed by opposition parties" (Cabinet Office n.d., 6). So it is not simply providing explanation of how policies are implemented but backing the "ministerial line" for why they are being implemented. This begins to beg the question of just how civil servants backing a ministerial line remain distinguishable from politically appointed advisers who are hired specifically to promote the government's political line.

With public service leaders increasingly becoming part of the public face of government, the propensity for perceptions of politicisation to grow becomes almost unavoidable. If public servants are asked to publicly represent the government at events, toe the "ministerial line" whilst doing so, provide as "positive" a view of things as they can and "justify" the thinking of ministers in the face of criticism, it would be incredible if perceptions of their politicisation did not follow. It places public servants in the invidious position that they can be professionally and impartially doing their job and yet become publicly tainted as partisan supporters of the government of the day. That is why the wording of codes, values and guidelines remains so important. They can provide a formal restraint that can slow down any informal push by political leaders for their public service to be more partisan in their support. 


\section{References}

AAP. 2010. 'Ken Henry a Gun for Hire, Say Coalition', The Australian, 25 May. <http://www.theaustralian.com.au/archive/politics/ken-henrys-mining-tax-figures-cant-betrusted-coalition/story-e6frgczf-1225870939831>. Accessed 2 December 2013.

Aberbach, J. D., R. D. Putnam and B. A. Rockman. 1981. Bureaucrats and Politicians in Western Democracies. Cambridge, MA: Harvard University Press.

APSC. n.d. "Sect 1.5 Involvement of public servants in public information and awareness initiatives." Canberra. APSC. <http://www.apsc.gov.au/publications-and-media/currentpublications/aps-values-and-code-of-conduct-in-practice/involvement-of-public-servants-inpublic-information-and-awareness-initiatives>. Accessed 16 September 2013.

APS Commissioner. 2013. APS Commissioner's Directions. Canberra: APSC. <http://www.comlaw.gov.au/Details/F2013L00448>.

Aucoin, Peter. 2012. "New Political Governance in Westminster Systems: Impartial Public Administration and Management Performance at Risk." Governance 25 (2): 177-199.

Bell, Stephen. 2011. "Do We Really Need a New 'Constructivist Institutionalism' to Explain Institutional Change?" British Journal of Political Science 41 (4): 883-906.

Boston, Jonathan. 2012. "Reflections on 'New Political Governance in Westminster Systems'." Governance 25 (2): 201-205.

Boston, J. and J. Halligan. 2012. "Political Management and New Political Governance: Reconciling Political Responsiveness and Neutral Competence." In From New Public Management to New Political Governance, ed. H. Bakvis and M. Jarvis. Montreal \& Kingston: McGill-Queen's University Press. 
Bourgalt, J. 2011. "Canada's Senior Public Service and the Typology of Bargains: from the Hierarchy of Senior Civil Servants to A Community of 'Controlled' Entrepreneurs." Public Policy and Administration 26 (2): 253-275.

Cabinet Office. (n.d.) Propriety Guidance. London: Cabinet Office. <https://gcn.civilservice.gov.uk/wp-content/uploads/2011/02/propriety-guidance.pdf>

Cabinet Office. 2000. Directory of Civil Service Guidance. 2 vols. London: Cabinet Office. <https://www.gov.uk/government/publications/directory-of-civil-service-guidance>.

Civil Service Code. 2010.<http://www.civilservice.gov.uk/wpcontent/uploads/2011/09/civil-service-code-2010.pdf>. Accessed 9 December 2013.

Dixon, J., A. Kouzmin and N. Korac-Kakabadse. 1996. "The Commercialization of the Australian Public Service and the Accountability of Government: A Question of Boundaries." International Journal of Public Sector Management 9 (5/6): 23-36.

Furi, Megan. 2008. Public Service Impartiality: Taking Stock. Ottawa: Public Service Commission of Canada. <http://www.psc-cfp.gc.ca/plcy-pltq/rprt/impart/impart-eng.pdf>. Accessed 16 September 2013.

Government of Canada. 2011. Values and Ethics Code for the Public Sector. Ottawa: Government of Canada. < http://www.tbs-sct.gc.ca/pol-cont/25049-eng.pdf>. Accessed 16 September 2013.

Harper, S. (2006) "Accountability and the Public Service." Ottawa. 23 March. <http://pm.gc.ca/eng/media.asp?category=2\&featureld=6\&pageld=46\&id=1073>.

Hennessy, Peter. 2000. The Prime Minister: The Office and Its Holders since 1945. London: Penguin. 
Kernaghan, Kenneth. 1979. "Power, Parliament and Public Servants in Canada: Ministerial Responsibility Reexamined." Canadian Public Policy 5 (3): 383-396.

Lindquist, E. and K. Rasmussen. 2012. “Deputy Ministers and New Political Governance: From Neutral Competence to Promiscuous Partisans to a New Balance?" In From New Public Management to New Political Governance, ed. H. Bakvis and M. Jarvis. Montreal \& Kingston: McGill-Queen's University Press.

Institute for Public Policy Research. 2013. Accountability and Responsiveness in the Senior Civil Service, London: Cabinet Office.

Mulgan, Richard. 2007. "Truth in Government and the Politicization of Public Service Advice." Public Administration 85 (3): 569-586.

Mulgan, Richard. 2008. "How Much Responsiveness is Too Much or Too Little?" The Australian Journal of Public Administration 67 (3): 345-356.

Nethercote, J. R. 2012. "Reflections on 'New Political Governance in Westminster Systems'." Governance 25 (2): 205-207.

Parkinson, Martin and David Tune. 2013. "Statement on Costings by the Department of the Treasury and the Department of Finance and Deregulation." Joint media release with the Department of Finance and Deregulation. <http://www.treasury.gov.au/PublicationsAndMedia/MediaReleases/2013/CostingsStatement>. Accessed 17 September 2013.

Podger, Andrew. 2007a. "What Really Happens: Department Secretary Appointments, Contracts and Performance Pay in the Australian Public Service." Australian Journal of Public Administration 66 (2): 131-47.

Podger, Andrew. 2007b. "Response to Peter Shergold." Australian Journal of Public Administration 66 (4): 498-500. 
PSCC. 2013. "Safeguarding non-partisanship in the public service." Public Service Commission of Canada Website. <http://www.psc-cfp.gc.ca/val/np-ip/index-eng.htm>. Accessed 16 September 2013.

Public Service Commission. 2009. Emerging Trends Affecting the Public Service Commission and the Public Service Employment Act. Ottawa: Public Service Commission.

<http://www.psc-cfp.gc.ca/abt-aps/rprt/psea-lefp/trends-tendances/index-eng.htm>.

Rhodes, Rod A.W., John Wanna and Patrick Weller. 2008. "Reinventing Westminster: How Public Executives Reframe Their World." Policy and Politics 36 (4): 461-479.

Rhodes, Rod A.W., John Wanna and Patrick Weller. 2009. Comparing Westminster. Oxford: Oxford University Press.

Rhodes, Rod A.W. 2011. Everyday Life in British Government. Oxford: Oxford University Press.

Ross, T. 2013. "MPs to Criticise Sir Jeremy Heywood over Plebgate Inquiry." The Telegraph, 20 January. <http://www.telegraph.co.uk/news/politics/9814037/MPs-to-criticise-SirJeremy-Heywood-over-Plebgate-inquiry.html>. Accessed 2 December 2013.

Shergold, Peter. 2007. "What Really Happens in the Australian Public Service: An Alternative View." Australian Journal of Public Administration 66 (3): 367-70.

Sparrow, A. 2013. "MPs Criticise Cameron and Heywood over 'Plebgate' Affair." The Guardian, 21 January 2013. <http://www.theguardian.com/politics/2013/jan/21/mpscriticise-cameron-heywood-plebgate>. Accessed 2 December 2013. 
State Services Commission. 2010a. Understanding the Code of Conduct - Guidance for State Servants. Wellington: State Service Commission. < http://www.ssc.govt.nz/code-guidancestateservants>. Accessed 16 September 2013.

State Services Commission. 2010b. Political Neutrality Guidance. Wellington: State Services Commission. <http://www.ssc.govt.nz/political-neutrality-guidance>. Accessed 16 September 2013.

Thomas, Paul. 2013. "Communications and Prime Ministerial Power." In Governing: Essays in Honour of Donald J. Savoie, ed. J. Bickerton and B.G. Peters. Montreal and London: McGill-Queen's University Press.

Treasury Board of Canada Secretariat. 2011. Duty of Loyalty. Ottawa: Treasury Board of Canada Secretariat. <http://www.tbs-sct.gc.ca/rp/icgtb-eng.asp>. Accessed 16 September 2013.

Treasury Board of Canada Secretariat. 2012. Communications Policy of the Government of Canada. Ottawa: Treasury Board of Canada Secretariat. <http://www.tbs-sct.gc.ca/pol/doceng. aspx?id=12316\&section=text>. Accessed 16 September 2013.

Van Dorpe, K and S. Horton. 2011. "The Public Service Bargain in the United Kingdom: The Whitehall Model in Decline?" Public Policy and Administration 26 (2): 233-252.

Wanna, John. 2008. "Independence and Responsiveness - Re-tying the Gordian Knot." The Australian Journal of Public Administration 67 (3): 34-344.

Weller, Pat. 2001. Australia's Mandarins: The Frank and the Fearless? Crows Nest NSW: Allen and Unwin.

Wilson, Graham K. and Anthony Barker. 2003. "Bureaucrats and Politicians in Britain." Governance 16 (3): 349-372. 